\title{
Abolishing Income Tax Deductions for Work-Related Expenses
}

\author{
Jonathan Baldry
}

U

NDER the Australian personal income tax, wage and salary earners are allowed to claim tax deductions for work-related expenses (WREs). In income year 1993/94, 67 per cent of wage and salary earners (59 per cent of all personal income taxpayers) claimed deductions for WREs amounting to $\$ 4.86$ billion, or 2.6 per cent of total declared wages and salaries. The most important component of the claims was for 'other work-related expenses', which includes tools, professional and trade journals, subscriptions to professional bodies, and conference fees; the total claimed amounted to $\$ 2.05$ billion. The second most important category was motor vehicle claims, which totalled $\$ 1.54$ billion. ${ }^{1}$ The most common claims were again for 'other work-related expenses' $(4.10 \mathrm{~m}$ taxpayers) and 'uniforms and laundry expenses' $(2.86 \mathrm{~m}$ taxpayers).

For most of these taxpayers, calculating claims for WRE deductions represent the major and often the only complication in completing the tax return. WRE deductibility is a major factor in the high compliance costs associated with the Australian personal income tax. It also generates a range of distortions and consumption caused by the implicit subsidies it gives to certain activities. Contrary to its presumed purpose, it seems to undermine the equity of the tax system: the differential access to deductible WRFs available to the various occupational groups introduces an arbitrary element into the distribution of effective post-tax income, while in general conferring significant tax advantages on the better-off. These undesirable consequences together make a compelling case for the total or partial abolition of WRE deductibility in Australia, a move which would also put the Australian tax system in line with practice in the majority of developed economies. New Zealand, for example, abolished WRE deductibility in 1987.

\section{The Law and Practice of WRE Deductions in Australia}

Personal income taxpayers have been able to claim deductions for WREs since the first Income Tax Assessment Act (ITAA) of 1915. The relevant part of the 1936

\footnotetext{
Jonathan Baldry is Associate Professor of Economics at The University of New England.

${ }^{1}$ Unless otherwise stated, all data are derived from the relevant annual volume of the Taxation Statistics published by the Australian Taxation Office, Canberra.
} 
ITAA, which (with amendments) defines current income tax law, is Section 51(1). This section defines an allowable 'general deduction' in these terms:

\begin{abstract}
All losses and outgoings to the extent to which they are incurred in gaining or producing assessable income, or are necessarily incurred in carrying on a business for the purpose of gaining or producing income, shall be allowable deductions except to the extent to which they are losses or outgoings of capital, or of a capital, private or domestic nature, or are incurred in relation to the gaining or production of exempt income.
\end{abstract}

To be a legitimate deduction, a particular expense must be related to (but not necessarily required for) the generation of income. It must not be an expense being used to build up the wealth of the taxpayer. As well, the expense must be one which would not normally be incurred in a non-employment context - for example, as a cost associated with consumption or with non-market, non-taxable production. An interpretation of this qualifying clause is that an expense which generates a direct gain ('utility'), or an indirect gain through the production of non-assessable income, shall not be allowable, because the direct or indirect gain is itself not taxed.

The main sources of interpretation of s.51(1) are legal judgments on appeals against assessments and the Australian Taxation Office's (ATO's) system of Rulings and Determinations. Determinations are a more recent innovation, which generally relate to the circumstances of particular occupational groups or to particular types of expenses. The large body of Determinations and Rulings has resulted in some general principles, many arbitrary and often contradictory distinctions, and a number of rules of thumb concerning 'reasonable limits' for particular types of WREs. One rule of thumb concerns the substantiation requirements for WREs in aggregate. In the ATO's 1996 TaxPack, it is stated that 'you must be able to substantiate ... your claims if the total claimed is greater than $\$ 300^{\prime}$. However, for smaller total claims, 'you need to be able to show how you worked out your claims ... you do not need written evidence' (p. 48). A recent crackdown on tax agents who automatically claim close to $\$ 300$ in WRE deductions for all of their clients has shown that the $\$ 300$ guide is not to be interpreted as a standard deduction.

The notion of 'reasonable limits' is a recognition that WRE deductions may be (improperly) used to subsidise consumption, or to promote other non-work purposes, if no restrictions are defined. The various interpretations of s.51(1) as it applies in particular groups of cases aim to establish both the relevance of an expense to an occupation and the extent to which the expense would be likely to be incurred in another context. This latter condition, which reflects the second, limiting clause of s.51(1), lies at the heart of most Rulings and Determinations related to WREs, and produces most of the arbitrariness and contradictions. For example, a

${ }^{2}$ The status and nature of Determinations are detailed in the first of a new series of Determinations, reference TD 92/100. A previous series of Determinations was issued on capital gains matters, and numbered CGT $1-60$. 
shearer may claim deductions for jeans used as working clothes (TD 94/48), even though many people buy and wear jeans, and many shearers would buy them as non-working clothes. By contrast, the clothes worn by plain-clothes police officers are not allowable deductions (TR 95/13). Flight attendants, required to be wellgroomed on the job, cannot claim personal grooming expenses (TR 95/19) (as distinct from moisturisers, hair conditioners and the like, which are allowable deductions in recognition of the harsh working environment), while physical training instructors are able to claim the off-the-job costs of keeping fit, which is a necessary requirement for their occupation (TD 93/110).

Such arbitrary and inequitable outcomes arise because whereas it is easy to establish that a particular expense is associated with a particular occupation, it is difficult to establish that a group of people would not have incurred certain expenses if they had not had the particular occupation. For this reason, most of the Rulings and Determinations relate to the qualifying clause of s.51(1). The notable exception, which has generated a major anomaly, concerns deductions for self-education. To be a legitimate deduction, this expense must be related to a taxpayer's current occupation and required for continuation or advancement in this occupation. But self-education expenses unrelated to the current occupation cannot be claimed as deductions, even if they will (or can) lead to a higher-paying occupation." As well, self-education expenses only in excess of $\$ 250$ a year are deductible, even though no such restriction applies to other WREs.

\section{Who Claims WRE Deductions?}

High-income taxpayers and those in a small number of (generally highly-paid) occupations make much more use of the deductibility provision than others. Highincome earners are big claimers of all types of WRE deductions, except for uniforms and laundry expenses. With this exception, both the proportions of wage and salary earners claiming, and the size of the average claim, increase with income for all categories of WREs. Regression analysis using 1993-94 ATO occupational data shows that the size of the average claim in each category, and the size of the average claim for all WREs, are more sensitive to income or salary than is the proportion claiming. An increase in annual salary of $\$ 1,000$ leads on average to an increase of 0.4 per cent in the proportion claiming any WRE deductions. For individual WRE categories, the changes in proportions claiming range from minus 0.3 per cent per $\$ 1,000$ increase in salary for 'uniforms and laundry' (the only category for which the proportion claiming decreases with income) to 0.9 per cent for the 'other' category. The size of the average WRE claim increases by $\$ 49$ per $\$ 1,000$ increase in salary, with the changes in the different categories ranging from zero for laundry and clothing expenses to $\$ 35$ for 'other' expenses. Overall, the most income-sensitive claims are those in the 'other' category, which includes conferences,

\footnotetext{
3

Mansfield v FCT (1995) 31 ATR 367.

4

SeeFCT $v$ Wilkinson (1983) ATC 4295.
} 
books and journals, tools, and professional and union subscriptions. 'Other travel' and motor vehicle claims are the next most income-sensitive categories.

Table 1: Characteristics of WRE claims by five highest-claiming occupations

\begin{tabular}{|c|c|c|c|c|c|c|c|c|c|}
\hline \multirow[b]{2}{*}{$\begin{array}{l}\text { Occ. } \\
\text { code }\end{array}$} & \multirow[b]{2}{*}{$\begin{array}{l}\text { Ave. } \\
\text { salary } \\
\text { (\$) }\end{array}$} & \multirow[b]{2}{*}{$\begin{array}{l}\text { Ave. } \\
\text { income } \\
\text { (\$) }\end{array}$} & \multicolumn{6}{|c|}{$\begin{array}{l}\text { Percentage claiming } \\
\text { (average claim }(\$) \text { ) }\end{array}$} & \multirow{2}{*}{$\begin{array}{l}\text { Ave. } \\
\text { claim } \\
\text { as } \\
\% \text { of } \\
\text { salany }\end{array}$} \\
\hline & & & Motor & Travel & Clothing & $\begin{array}{l}\text { Educ- } \\
\text { ation }\end{array}$ & Other & Total & \\
\hline 11 & 45,808 & 62,910 & $\begin{array}{c}46 \\
(4,367)\end{array}$ & $\begin{array}{c}27 \\
(4,822)\end{array}$ & $\begin{array}{c}14 \\
(192)\end{array}$ & $\begin{array}{c}5 \\
(1,461)\end{array}$ & $\begin{array}{c}92 \\
(8,179)\end{array}$ & $(10,776)$ & 20.3 \\
\hline 61 & 32,440 & 40,193 & $\begin{array}{c}70 \\
(5,410)\end{array}$ & $\begin{array}{c}12 \\
(1,641)\end{array}$ & $\begin{array}{l}16 \\
(201)\end{array}$ & $\begin{array}{c}7 \\
(768)\end{array}$ & $\begin{array}{c}89 \\
(1,692)\end{array}$ & $(5,634)$ & 14.4 \\
\hline 23 & 48,258 & 61,380 & $\begin{array}{c}44 \\
(2,455)\end{array}$ & $\begin{array}{c}13 \\
(1,412)\end{array}$ & $\begin{array}{c}32 \\
(179)\end{array}$ & $\begin{array}{c}12 \\
(1,437)\end{array}$ & $\begin{array}{c}92 \\
(2,121)\end{array}$ & $(3,448)$ & 5.7 \\
\hline 33 & 53,092 & 56,063 & $\begin{array}{c}22 \\
(1,185)\end{array}$ & $\begin{array}{c}28 \\
(3,062)\end{array}$ & $\begin{array}{c}69 \\
(210)\end{array}$ & $\begin{array}{c}7 \\
(2,076)\end{array}$ & $\begin{array}{c}95 \\
(1,356)\end{array}$ & $(2,699)$ & 4.8 \\
\hline 25 & 32,192 & 35,835 & $\begin{array}{c}48 \\
(922)\end{array}$ & $\begin{array}{c}20 \\
(2,077)\end{array}$ & $\begin{array}{c}22 \\
(207)\end{array}$ & $\begin{array}{c}14 \\
(1,179)\end{array}$ & $\begin{array}{c}95 \\
(1,269)\end{array}$ & $(2,246)$ & 6.2 \\
\hline
\end{tabular}

Occupational codes: 11: Legislators and government-appointed officials (including judges). 61: Investment salespersons. 23: Health diagnosis and treatment practitioners (medical practitioners, etc.). 33: Air and sea transport employees. 25: Other teachers and instructors (including lecturers). Since the average (\$) claims in each category refer only to the amounts claimed by those claiming the relevant deduction, the average total amount claimed by those claiming any deductions is not the sum of the averages for the individual categories.

Source: Unpublished ATO data, 1993/94.

Table 1 shows that WRE tax deductions are extremely important for a small group of occupations, and are spread non-randomly around the employed population in terms of proportions claiming, average claim, and the ratio of average claim to income. If these WREs contain a large consumption component, then the groups listed in Table 1 are effectively receiving an income subsidy from the tax system. If, by contrast, the WREs are 'purely productive' and contain a zero consumption component, then the groups listed are being only partially protected by the tax system from necessary costs of employment. For example, a person on a 30 per cent tax rate required to purchase $\$ 100$ of work-related items with zero consumption benefits receives only a 30 cents in the dollar cushion from the income tax against such expenses.

The degree to which WRE deductibility may affect the after-tax distribution of 'true' income is illustrated in Table 2. Deductibility is of the greatest benefit to highincome taxpayers in proportional terms. Although the ratio of claims to average wages and salaries decreases slightly as income increases, the effects of increasing marginal tax rates in the upper-income ranges, which make WREs more valuable to taxpayers, tends to offset this. However, if all WREs claimed are 'phantom' WREs (those that they are not required to perform a job and do not increase productivity) with a 100 per cent consumption component, the impact of deductibility is broadly neutral, though low- and medium-income taxpayers gain least in proportional terms, 
and high-income taxpayers the most. If WRE claims relate to 'purely productive' items of expenditure, then, in the absence of labour market adjustments which would compensate employees for particular expenses of work, deductibility clearly protects those on low incomes. To some degree, though, it provides even more 'protection' to high-income taxpayers. To remove deductibility would in the short run make the income tax slightly more progressive.

Table 2: WRE tax subsidies and income

\begin{tabular}{lccccc}
\hline $\begin{array}{l}\text { Taxable } \\
\text { income }\end{array}$ & $\begin{array}{c}\text { Ave. salary } \\
\text { (\$) }\end{array}$ & $\begin{array}{c}\text { Ave. } \\
\text { WRE } \\
\text { claim }(\$)\end{array}$ & $\begin{array}{c}\text { Ave. WRE } \\
\text { as \% of } \\
\text { salary }\end{array}$ & $\begin{array}{c}\text { Ave. tax } \\
\text { benefit }(\$)\end{array}$ & $\begin{array}{c}\text { Tax benefit } \\
\text { as \% of } \\
\text { salary }\end{array}$ \\
\hline Below 10,000 & 8,063 & 344 & 4.3 & 69 & 0.9 \\
$10,000-14,999$ & 11,824 & 386 & 3.3 & 77 & 0.7 \\
$15,000-19,999$ & 16,946 & 492 & 2.9 & 98 & 0.6 \\
$20,000-24,999$ & 21,957 & 552 & 2.5 & 196 & 0.9 \\
$25,000-34,999$ & 29,282 & 741 & 2.5 & 263 & 0.9 \\
$35,000-49,999$ & 40,354 & 1,033 & 2.6 & 456 & 1.1 \\
$50,000+$ & 66,861 & 1,486 & 2.2 & 698 & 1.0 \\
\hline
\end{tabular}

Notes: Average Wages and Salaries are averages for each taxable income group. Average WRE claim is the average for those who claim. Tax benefit is computed by applying the relevant marginal tax rate to the average claim for each group.

Source: Computed from Australian Tax Office, Taxation Statistics, 1993-94, AGPS, Canberra, 1995, Table 1.2.

However, given that (as shown below) labour markets adjust in the long run to compensate employees for particular expenses of employment, deductibility provides short-run protection only: in the long run, the impact would largely be neutral when WREs are purely productive. The shares of the subsidy and protection components of WRE deductions are unknown, but this does not affect the equity argument for abolition. If deductions subsidise consumption, then, regardless of whether the subsidy is progressive or regressive, they should be abolished and the progressivity of the tax system should be made transparent through the rate structure itself. If WREs are purely productive, then the protection afforded by deductibility is not needed in the long run.

\section{The Equity Impact}

In the apparent absence of any explicit justification for tax deductibility of WREs in any of the parliamentary debates leading up to the first ITAA in 1915 or in any subsequent debates or official publications, it is implicitly justified by reference to equity considerations.

Suppose occupations A and B each pay a gross wage of $\$ 500$ a week, but B requires the employee to purchase items costing $\$ 100$ for use on the job as a condition of employment. Initially, suppose too that the WRE items are purely productive and have zero value to the employee outside the workplace. They are essentially just productive inputs which, for whatever reason, are supplied by the employee rather than the employer. Finally, assume that there is a fixed income tax rate of 30 per cent. 
Without deductibility, employees in each occupation have $\$ 350$ a week after tax, but the B-employee is left with only $\$ 250$ after paying for the required WREs. If WREs are tax-deductible, the position of the A-employee is unchanged. However, the B-employee's taxable income is now only $\$ 400$, on which tax of $\$ 120$ is payable. Take-home pay is thus $\$ 380$, of which $\$ 100$ is needed for WREs. This leaves the B-employee with $\$ 280$, which is still less than the A-employee's $\$ 350$. Nevertheless, the broad principle of 'vertical equity' is satisfied. At its most general, this principle states that tax contributions should be related to ability to pay, as measured by gross income. The true gross incomes of the two employees are $\$ 500$ for $A$ and $\$ 400$ for B, after subtracting necessary WREs. Since A pays more tax than $B$, vertical equity is satisfied. Without deductibility, the principle is violated, since each pays the same amount of tax even though A's true gross income is higher after allowing for B's expenditure on purely productive WRE items.

Deductibility of WREs is also consistent with the principle of horizontal equity, which holds that people with the same capacity to pay as measured by gross income should pay the same taxes. Consider a person in occupation $\mathrm{C}$, with a pre-tax income of $\$ 600$ a week, out of which $\$ 100$ is required for necessary WREs which generate no consumption benefits. True gross income of a C-employee is $\$ 500$. With deductibility, this employee pays tax of $\$ 150$, the same as an A-employee with pre-tax income of $\$ 500$ and no WREs. Without deductibility, the C-employee pays $\$ 180$, which violates the principle of horizontal equity since $\mathrm{A}$ and $\mathrm{C}$ have the same true gross incomes.

The equity rationale of WRE deductibility is superficially plausible. But it assumes that there are no consumption benefits derived from WRE items and that wages paid do not adjust to the relative costs or benefits associated with taxdeductible WREs. Consider the question of consumption benefits. Most WRE items can, in practice, generate (often significant) private benefits for those incurring the expenditure; and if the WREs are tax deductible, private consumption is effectively subsidised. A building worker's tools can be used for non-market and nontaxable activities, such as home renovations. Work-related travel costs can be used to finance leisure travel. Books purchased for professional purposes can, depending on the nature of the profession, generate significant consumption benefits: a teacher of English literature could have a 'professional library' consisting of books which most of us would buy purely for leisure reading. True, the extent to which deductibility can be used to subsidise private consumption is limited by legal judgments and Rulings and Determinations, as well as the ATO's procedures and rules of thumb and the apportionment provision in s.51(1), which requires that particular expenses are apportioned between work-related expenses and those which are private in nature. But varying levels of subsidy are an inherent feature of such openended opportunities, especially if procedures designed to prevent abuse and to clarify the employee's rights and duties are imperfect in their effects.

Such subsidies have some adverse efficiency implications (considered below). To the extent that their impact is not moderated by market forces, they also have clear and effectively arbitrary equity implications. As well, the big-ticket items, like 
motor vehicles, 'other travel', and 'other' WREs, are concentrated among the higher-income groups, and so make the income tax effectively less progressive.

These observations assume that labour markets do not adjust for the differential consumption benefits, or indeed, where these are zero or are outweighed by the non-consumption characteristics of WRE items, for the differential costs associated with the WRE requirements of particular occupations. However, depending on the flexibility of labour markets and the ease of entry into particular occupations, some adjustment could reduce the arbitrary equity impact of deductibility. If the WRE items required by a particular occupation do not generate any consumption benefits, workers entering that occupation will require compensation for the additional net-of-tax costs associated with that occupation. If, for example, $\$ 100$ of WREs with no consumption benefits are required, the supply price of labour to that occupation will increase by $\$ 100$ by comparison with similar occupations with no WRE requirements: with a tax rate of 30 per cent and deductibility of WREs, a wage increase of $\$ 100$ will give a worker a net wage increase of $\$ 100$ if this is matched by deductible WREs of $\$ 100$; and after this amount is spent on WRE items, there is no change in the amount available for private consumption. If the supply of labour to the occupation were perfectly elastic, the gross wage would rise by $\$ 100$ in this case. But in general, the outcome would be a rise of less than $\$ 100$ and a decrease in employment in that occupation: the workers who remain in the occupation would be less well off than they would have been without the WREs-plusdeductibility, but they would not be $\$ 70$ worse off, which would be the case if there were no labour market adjustment.

At the other extreme, where all WREs are 'phantom', WRE deductibility is one of the non-wage benefits of the job. Depending on how much they value these benefits, workers will be willing to work in this occupation for a lower wage than for comparable occupations without access to the WRE consumption subsidy. The supply price of labour to this occupation will be lowered by comparison with similar occupations if the labour market is at all flexible, and to this extent the consumption subsidy is partly offset by a lower wage. Employer-provided on-the-job benefits have a similar impact.

To summarise: while the arbitrary equity impact of WRE deductibility may be to some extent moderated by market forces, neutralisation is not perfect. Deductibility to some extent protects workers from incurring 'true' WREs from their costs, but not perfectly. At the same time, where there is a large consumption component, market reactions will to a degree moderate the benefits of the de facto consumption subsidy, but not perfectly.

Of themselves, these arguments do not constitute an overwhelming case for the abolition of WRE deductibility on equity grounds, because the position of workers required to incur 'pure' WREs which generate no consumption benefits would arguably be worse without deductibility, even if abolition of deductibility were to eliminate the consumption subsidy going to certain occupations. This would be true if workers incurring pure WREs were to continue shouldering this expense after abolition (though if this were the case, market forces could again be expected 
to moderate the impact). However, it is likely that abolition of WRE deductibility would shift the cost of these items from employee to employer.

\section{Shifting the Cost of WREs to Employers}

'Pure' WRE items are simply productive inputs which happen to be supplied by employees rather than employers. For such inputs to be supplied by employees, the relevant items must be comparatively cheap, because an employee would otherwise be unlikely to be able to afford them. With WRE deductibility for employees, it is a matter of indifference in the long run (allowing for labour market adjustments) to both employer and employees who shoulders the cost.

Suppose the assumptions of the earlier example hold (WREs of $\$ 100$, with a 30 per cent employee tax rate) and, in addition, the tax rate on the employer's profit is 40 per cent. If the cost of the WRE items is shifted from employee to employer, then the employer's net profit is reduced by $\$ 60$ per employee, which is the net cost of the employer's increased expenditure on WRE items. However, holding employment constant, the gross wage will fall by $\$ 100$, reflecting the elimination of the employee's WRE cost, and this will increase net profit by $\$ 60$. The overall impact is that the net positions of both employer and employee are unchanged.

Why then do employees bear the cost - as WREs - of some productive inputs? One possible explanation is that use of the relevant inputs is difficult to control, and that the employer saves on monitoring costs by letting the employee bear the cost of the WRE items. A more likely explanation is that deductibility of WREs generates some consumption benefits, and that letting the employees bear the burden of deductible WREs is a way of capturing a wage subsidy. Suppose that while $\$ 100$ of WREs are required for 'purely productive' purposes, access to deductibility also allows the employee to receive a tax subsidy by purchasing in excess of this, because the operation of the tax law in practice does not allow for determination of what is 'really' required for the job. If these consumption benefits are worth $\$ 300$ (as measured by the increased consumer surplus accruing to the employee), then the net impact of deductibility is a benefit to the employee of $\$ 230$, which is the consumption benefit minus the net cost of the purely productive WREs. If the cost of the WRE items were shifted to the employer, the employer would (presumably) pay only for the 'purely productive' items ( $\$ 100$ gross), which reduces net profit by $\$ 60$ per worker. If employees retain their access to deductions for the alleged WREs they purchase for consumption benefits, their wage would fall by $\$ 100$; they would be no worse off (because they do not now bear the $\$ 100$ of purely productive WREs), and this wage reduction would offset the increased expenditure by the employer on WRE items. However, if employer responsibility for these items means that the deductions formerly available to the employees (the effective tax subsidy for consumption) are withdrawn, employees will require a wage increase of $\$ 428$, which is the gross value of the consumption subsidy forgone. Hence, overall, employees would receive a wage increase of $\$ 328$ to get them back to their original position, while the employer would incur increased costs of $\$ 328$ per employee, which is a reduction of $\$ 197$ in net profit. 
While market adjustments would generally ensure that the final outcome would be a loss shared between employer and employees, this example shows that deductibility of WREs for employees is attractive to both. So long as there are any consumption benefits associated with tax deductibility of WREs for employees, this provides an effective wage subsidy, and any wage subsidy, whether implicit or explicit, is attractive to both sides. But what is important in this case is that this type of subsidy (WRE deductibility) provides an incentive for the employer to leave the responsibility for supplying particular types of productive inputs - those which are deductible for employees and provide consumption benefits - in the hands of employees. If deductibility were abolished, the incentive would largely disappear.

\section{Implications for Allocative Efficiency}

A slight modification to the previous example shows that deductibility may have adverse efficiency implications. The simple modification required is to recognise that the amounts of productive WRE-type inputs used by an employer are affected by their net cost.

In a world with no tax-deductibility of WRE items for employees, though such items are de facto tax-deductible for employers, it is a matter of indifference (for employers and employees) as to who bears the cost. This was demonstrated in an earlier example. It was also demonstrated there that if employee finance of WRE items is accompanied by employee tax deductibility of WREs, and if access to deductibility allows employees to benefit from an effective consumption subsidy, then there are net joint gains to be made by employers and employees from shifting the costs of WRE items to employees. The division of the net gains would depend on the nature of the labour market (and in particular on the elasticities of supply and demand for labour), but in general both employees and employer would expect to share in the spoils.

So long as employers share in these gains from WRE deductibility, the effective net price to the employer of the WRE items required for purely productive purposes will be lowered, as will the effective price of hiring an employee. In total, the price of a 'package' consisting of an employee plus the productive items required by that employee will be lower than otherwise, and the employer will hire more such packages than otherwise. (Strictly speaking, this argument assumes that there is no substitutability between workers and WRE items in production. If this is not true, the composition of the chosen 'package' will vary depending on the productivity of the two component of the package. However, the essentials of the argument are not affected.)

It is a standard proposition in economics that if a profit-maximising enterprise pays the full price for an input and sells its output in a competitive market, that input will be used at the efficient level as defined above. An input which is subsidised will generally be over-used, and a taxed input under-used. In the absence of the subsidy provided by tax deductibility of WREs, items which generate consumption benefits for employees, labour and the WRE inputs will be used at their efficient levels. With the subsidy, they will be over-used. This is the basis for the allocative 
inefficiency argument. The cost of these inefficiencies is a matter for conjecture, but is probably small. But in the present context they provide a further reason for abolishing WRE deductions for employees.

However, a further efficiency cost should be taken into account. Insofar as employees purchase some WRE items purely for the consumption benefits they generate, and since tax deductibility for these items lowers their effective cost to employees, these items will be consumed more than otherwise. This is a distortion in that the consumption value of these items to the relevant occupational groups is, at the margin, lower than the value to other groups, and lower than the marginal cost of production. Again, the magnitude of the costs involved is conjectural, but the argument for removing the tax subsidy on these grounds is similar to the argument for moving towards a general consumption tax as a means of correcting a distorted consumption pattern.

\section{Compliance Costs}

The compliance costs of tax deductibility of WREs alone provide a compelling case for abolishing them. Such costs comprise the time, money and effort incurred by taxpayers in particular, and by the private sector in general, in attempting to satisfy their tax obligations. The only comprehensive study of income tax compliance costs in Australia was that carried out in income year 1986/87 by Pope, Fayle and Duncanson (PFD) (1990), who used the sample survey method employed by a number of international researchers. This technique has been criticised on a number of grounds (Rimmer \& Wilson, 1996). Most important, it may improperly identify costs incurred for other reasons as compliance costs, and the often low response rate (only 16.3 per cent in the PFD study) generates doubts about the randomness of the effective sample, since self-selection by those taxpayers who find compliance particularly irksome and costly is quite likely. These factors could exaggerate their estimates, perhaps by as much as 50 per cent. This possibility is allowed for in what follows.

On the other side of the ledger, since the PFD study the personal income tax system in Australia has undergone many radical changes, the introduction of selfassessment and TaxPack (in 1987) being the most important. These changes are likely to have had a considerable and positive impact on compliance costs, especially for wage and salary earners. Some indication of this is given by the increase in tax agent use associated with self-assessment and TaxPack (Baldry \& McKinstry, 1995). To an unknown extent, these changes are likely to have partially offset any over-estimates in the PFD study.

The PFD study estimated personal income taxpayer compliance costs at 10.4 per cent of income tax revenue. A rough estimate of the amount which would be saved by abolition of WRE deductibility can be obtained by using those PFD estimates which relate to the type of tax return form completed.

In 1986/87, salary and wage-earners were required to complete and lodge Form $\mathrm{S}$, so long as dividend and interest income was moderate, and so long as income was not earned from other major sources such as trusts, selfemployment and rental 
property. In short, Form $S$ was the form which most wage and salary earners without other significant income would lodge. Form S-lodging taxpayers would presumably find their affairs considerably simplified if they could not claim WREs as deductions. The only major exceptions would be those taxpayers whose income was largely derived from pensions and unemployment, sickness or other benefits. An extreme assumption is that compliance costs for all Form $S$ taxpayers would be reduced to zero by abolition of WRE deductions. A more moderate assumption is that these costs would be reduced by 50 per cent. Using the PFD data, rough calculations following from these assumptions suggest a reduction in compliance costs from 10.4 per cent to either 7.98 or 9.2 per cent of revenue, depending on the assumption made.

Using the data given in PFD (Table 5.5), the savings for low-income taxpayers would be between 2.3 and 1.15 per cent of taxable income, and, for high-income taxpayers, between 0.45 and 0.9 per cent of taxable income. Since about half of the total compliance costs for the average taxpayer comprise time costs, abolition of WRE deductions would not generally lead to massive visible savings for wage and salary earners, but rather a saving in time, frustration and worry, heavily concentrated around the end of the tax year. However, there would be visible monetary savings as well, especially in tax agents' fees, for many taxpayers. Possibly 30 per cent or more of taxpayers would cease to use the services of tax agents. Currently about 72 of cent of taxpayers use agents, though the proportion for wage and salary eamers is probably much lower. Since data on agents' fees paid are not available, the tax agent savings cannot be estimated. However, the crude PFD data suggest that a 50 per cent reduction in compliance costs for salary and wage earners, where 50 per cent of the compliance costs saved are monetary, would lead to an estimated total monetary saving of 1.9 per cent of income tax revenue. If this figure were to be applied to current (1993/94) statistics, it would imply a saving of $\$ 905 \mathrm{~m}$, or $\$ 119$ for every taxable person.

These figures indicate that the gains available from abolition are not massive, but neither are they negligible. Moreover, other savings would result. Most important, the considerable effort which the ATO currently puts into compliance enforcement in respect of WRE claims could be diverted to other, more lucrative areas of enforcement.

\footnotetext{
${ }^{5}$ Table 5.4 of PFD presents the average estimated compliance costs of Form $\mathrm{S}$ taxpayers for each of four taxable income groups, and Table 5.5 lists the numbers of taxpayers in each income group. 64.8 per cent of taxpayers completed form $S$ (Table 3.4). The assumptions made here are, first, that each of the form $\mathrm{S}$ taxpayers in each group would save either all or 50 per cent of the average compliance costs listed in Table 5.4; and second, that 64.8 per cent of the taxpayers in each income group completed form $S$ (the numbers of form $S$ taxpayers in each group are estimated as 64.8 per cent of the total number of taxpayers in that group). Total savings are estimated as the average, or 50 per cent of the average, compliance costs for each group, multiplied by the estimated number of form $S$ taxpayers in that group. Total savings are estimated at $\$ 859 \mathrm{~m}$ or $\$ 430 \mathrm{~m}$. These figures are subtracted from the total compliance costs as estimated by PFD, and the result expressed as a percentage of the Net Tax, as reported in Table 2 of the 1986/87 Taxation Statistics.
} 
On the other hand, abolition of deductibility would provide more incentives for employees to become self-employed. The aim is to access the deductible business expenses which can provide (subsidised) consumption benefits. Employers have a similar incentive to do this, being able to economise on wages and avoid many of the other costs and regulations associated with employment (including the requirement to deduct tax at source under PAYE). The extent to which this would happen is unknown, given that self-employment involves a loss of benefits for employees and a less secure contract for employers. However, it is worth noting that the ATO has identified the self-employed as a high-risk area in terms of tax revenue, and is in the process of implementing procedures to limit the access of the self-employed to business expenses. In short, the ATO has the means of limiting the extent of this leakage of revenue, and shedding the enforcement costs associated with WRE deductions would release resources to tackle this area of revenue risk.

\section{The Real Challenge of Tax Simplification}

Abolition of WRE tax deductions would be a comparatively simple yet real structural reform to the income tax, and would generate net gains for the economy. It will cause losses to some groups in the economy, though less so in the long term (as labour markets adjust) than in the short term. Some employers are likely to oppose it as strongly as employees, because they would foresee the resultant pressures for wage increases and the need to bear some of the costs previously borne by employees. Other groups, especially those producing the over-used, tax subsidised items, would also object. However, unless the arguments presented here are refuted and a positive case made for the retention of deductibility, this provision of the tax law must be seen merely as historical baggage which remains a feature of the tax system simply because of inertia.

\section{References}

Baldry, J. \& K. McKinstry (1995), 'Explaining the growth in usage of tax agents by Australian personal income taxpayers', Australian Taxation Office Conference on Compliance Research, Canberra, December.

Pope, J., R. Fayle, \& M. Duncanson (1990), The Compliance Costs of Personal Income Taxation in Australia, 1986/87, Australian Tax Research Foundation, Sydney.

Rimmer, S. \& S. Wilson (1996), Compliance Costs of Taxation in Australia, Office of Regulation Review, Industry Commission, Canberra.

I am grateful to two anonymous referees for many helpful comments on an earlier version of this article. I am grateful also to John Gudgeon of the ATO for assistance in obtaining information on the occupational distribution of WRE claims which was kindly supplied by the ATO from its 1994 tax-return database while I was in residence during February 1996. Ludmilla Ruvinsky assisted with the statistical processing of the data. 